\title{
Penerapan Metode Pembelajaran Brainstorming untuk Meningkatkan Keterampilan Menulis Karangan Argumentasi di Sekolah Dasar
}

\author{
Ayu Shinta Saraswati \\ Universitas Sebelas Maret \\ ayushinta066@gmail.com
}

\section{Article History}

received 30/4/2021

\begin{abstract}
This research has a purpose to improve argumentative text writing skills by applying Brainstorming learning method for 5th grade students of SD Negeri Sukabumi in the 2020/2021 academic year. This was a Classroom Action Reasearch that consist of two cycles. The subjects of this research were 27 students of $5^{\text {th }}$ grade students of SD Negeri Sukabumi in the 2020/2021 academic year. Data collected by interviewing, observing, testing, and documenting technique. The data's validity in this research was done by using content validity, source triangulation, and tecnique triangulation. The data were analyzed by using statistic descriptive and interactive analysis. The initial conditions of argumentative text writing skills of 5th grade students showed 14, 81\% classically. Completeness at the end of first cycle reached $59 \%$ and increase to $81 \%$ at the end of second cycle. Based on the result of this study, it can be concluded that Brainstorming learning method could increase argumentative text writing skills 5 th grade students of SD Negeri Sukabumi in the 2020/2021 academic year.
\end{abstract}

Keywords: argumentative text writing skills, Brainstorming, elementary school

\begin{abstract}
Abstrak
Penelitian ini bertujuan untuk meningkatkan keterampilan menulis karangan argumentasi pada peserta didik kelas V SD Negeri Sukabumi tahun ajaran 2020/2021 dengan menerapkan metode pembelajaran Brainstorming. Bentuk dari penelitian ini berupa Penelitian Tindakan Kelas dengan dua siklus. Subjek penelitian merupakan 27 peserta didik kelas V SD Negeri Sukabumi Tahun Ajaran 2020/2021. Data dikumpulkan dengan menggunakan teknik wawancara, observasi, tes, dan dokumentasi. Validitas data diperoleh melalui triagulasi isi, sumber, dan teknik. Data dianalisis menggunakan analisis statistik deskriptif dan analisis interaktif. Kondisi awal keterampilan menulis karangan argumentasi peserta didik kelas $\mathrm{V}$ secara klasikal sebesar $14,81 \%$. Ketuntasan di akhir siklus I penelitian ini mencapai $59 \%$ dan meningkat menjadi $81 \%$ di akhir siklus II. Berdasarkan hasil penelitian tersebut, dapat ditarik simpulan bahwa penerapan metode pembelajaran Brainstorming dapat meningkatkan keterampilan menulis karangan argumentasi pada peserta didik kelas V SD Negeri Sukabumi Ajaran 2020/2021.
\end{abstract}

Kata kunci: keterampilan menulis karangan argumentasi, Brainstorming, sekolah dasar 


\section{PENDAHULUAN}

Pembelajaran abad 21 membutuhkan komunikasi yang tepat dan efektif. Bahasa Indonesia dapat menjadi alat dengan cara membelajarkan peserta didik meningkatkan keterampilan dan pengetahuan berbahasa, serta menghayati sastra Indonesia sebagai khazanah budaya (Atmazaki, 2013). Seperti yang dikemukakan Ngalimun \& Alfulaila (2014), pengajaran bahasa Indonesia bukan merupakan pengajaran tentang bahasa, melainkan pengajaran keterampilan berbahasa.

Terdapat empat ruang lingkup keterampilan berbahasa antara lain mendengar, berbicara, membaca, serta menulis. Mulyati (2015) mengemukakan bahwa mendengar (menyimak) dan membaca adalah keterampilan reseptif, sementara menulis serta berbicara adalah bagian dari keterampilan produktif. Keempat aspek tersebut saling berintegrasi.

Keterampilan menulis sebagai bagian dari keterampilan produktif memiliki kedudukan yang strategis dalam pengajaran. Syafi'e dalam Slamet (2013)menyatakan bahwa keberhasilan peserta didik dalam kegiatan pengajaran sering ditentukan dari keterampilan dalam menulis. Oleh karena itu, peserta didik perlu menguasai keterampilan menulis sedini mungkin. Peserta didik dilatih untuk mengungkapkan ide serta gagasan secara kritis dalam bentuk pembelajaran berbasis text (text-based teaching and learning) sebagai bagian dari Kurikulum 2013. Salah satunya dalam bentuk karangan. Slamet (2013) menyatakan terdapat lima ragam wacana dari karangan antara lain deskripsi, persuasi, narasi, eksposisi, serta argumentasi.

Sesuai dengan tujuan luaran Kurikulum 2013 yang mengharapkan peserta didik cakap, kritis, kreatif dan inovatif dalam mengembangkan pengetahuannya, maka keterampilan menulis karangan argumentasi menjadi alat yang esensial. Hal tersebut dikarenakan dasar utama dalam menulis karangan argumentasi adalah berpikir kritis, terampil bernalar, dan logis.

Argumentasi merupakan landasan mendasar dalam ilmu pengetahuan. Karangan argumentasi disusun sebagai usaha untuk membuktikan fakta atau memperkirakan kemungkinan sebagai dasar meyakinkan pembaca untuk menyatakan suatu sikap. Melalui karangan argumentasi, fakta dirangkai sedemikian rupa. Tujuan akhirnya adalah agar pembaca yakin dengan apa yang dibacanya. Peserta didik difasilitasi untuk berpikir kritis dalam menganalisis fakta yang ada di lingkungannya, terampil bernalar, dan menyusunnya dalam bentuk tulisan yang logis (Dalman, 2016).

Penilaian dan penelitian internasional secara konsisten mendokumentasikan kurangnya keterampilan dalam menulis karangan argumentasi. Dikutip dari Reznitskaya, Anderson, \& Kuo (2015) diketahui bahwa pada mayoritas peserta didik menunjukkan bahwa hanya sebagian kecil peserta didik (8\% kelas lima, 3\% kelas delapan, dan $6 \%$ kelas dua belas) dapat membuat penilaian, informasi kritis tentang teks tertulis. Hanya $2 \%$ peserta didik kelas lima dapat menyatakan posisinya secara konsisten dan mendukungnya dengan alasan yang baik. Persentase yang sama rendahnya juga terjadi tingkatan yang lebih tinggi. Peserta didik tidak dapat mengenali dan menerapkan struktur teks argumentatif. Mereka mengalami kesulitan untuk menemukan bukti asli, menawarkan alasan yang relevan serta bantahan.

Keterampilan menulis karangan argumentasi merupakan keterampilan yang membutuhkan latihan dan pembiasaaan. Latihan tersebut diperlukan dari langkah yang terstruktur dan mendetail yang terangkum dalam langkah operasional berupa metode pembelajaran. Selanjutnya penting untuk mengidentifikasi metode yang efektif untuk mendukung pengembangan argumentasi. Tepatnya pemilihan metode dapat merangsang peserta didik menuangkan ide gagasan dari berbagai sisi dalam bentuk tulisan dengan aktif.

Metode Brainstorming (Tukar Pikiran) merupakan metode pembelajaran untuk memunculkan ide dan solusi dalam bentuk argumentasi. Pembelajaran dengan menggunakan metode Brainstorming dilaksanakan dengan cara guru memberikan 
suatu topik atau isu kepada peserta didik. Selanjutnya setiap peserta didik dalam satu kelompok memberikan kata kunci berbeda yang nantinya dikembangkan dalam bentuk karangan argumentasi (Harianti \& Margaretha, n.d.: 177).

Metode Brainstorming merupakan cara untuk menghimpun berbagai argumen dalam waktu yang singkat. Satu argumen diusulkan oleh satu orang anggota dalam kelompok pada metode Brainstorming. Sehingga hasil karangan argumentasi dalam satu kelompok terdiri dari beberapa argumen sederhana.

Berdasarkan uraian di atas, rumusan masalah dari penelitian ini yaitu apakah penerapan metode pembelajaran Brainstorming dapat meningkatkan keterampilan menulis karangan argumentasi pada peserta didik kelas V SD Negeri Sukabumi tahun ajaran 2020/2021? Tujuan dari penelitian ini yaitu untuk meningkatkan keterampilan menulis karangan argumentasi melalui penerapan metode pembelajaran Brainstorming pada peserta didik kelas V SD Negeri Sukabumi tahun ajaran 2020/2021.

\section{METODE}

Jenis penelitian ini adalah Penelitian Tindakan Kelas (PTK). Penelitian ini dilaksanakan di SD Negeri Sukabumi, Kecamatan Cepogo, Kabupaten Boyolali selama 6 bulan. Dimulai dari bulan Januari sampai Juni 2021. Subjek dari penelitian ini adalah 27 peserta didik kelas V SD Negeri Sukabumi tahun ajaran 2020/2021. Data penelitian ini berupa hasil wawancara guru dan peserta didik, hasil pengamatan kinerja guru dan aktivitas peserta didik, dokumentasi pembelajaran (foto, vidio), dan hasil tes keterampilan menulis karangan argumentasi. Data penelitian ini bersumber dari sumber data informan yaitu guru kelas, sumber data penerima tindakan yaitu peserta didik, dan dokumen. Pengumpulan data dilakukan melalui teknik wawancara, observasi, tes keterampilan menulis karangan argumentasi, dan dokumentasi. Penelitian ini menggunakan teknik validitas isi, sumber, dan teknik. Data dianalisis menggunakan analisis statistik deskriptif dan analisis interaktif. Miles dan Huberman meliputi pengumpulan data, reduksi data, penyajian data, dan penarikan simpulan. Indikator penelitian ini sebesar $80 \%$ atau sejumlah 22 peserta didik masuk kategori tuntas (nilai $\geq 70$ ).

\section{HASIL DAN PEMBAHASAN}

Penelitian ini dilaksanakan dalam dua siklus dengan setiap siklus terdiri dari dua pertemuan. Tahapan pelaksanaan pada setiap siklus diawali dengan guru menjelaskan aturan dalam melaksanakan metode Brainstorming. Peserta didik diberikan waktu diam menemukan gagasan masing-masing. Dilanjutkan dengan peserta didik mengemukakan gagasan terkait dengan topik gagasan secara bergantian dalam kelompoknya. Pengumpulan argumen dan gagasan dihentikan ketika sudah tidak terdapat lagi ide yang ingin disampaikan atau waktu sudah habis. Peserta didik diberikan waktu untuk istirahat (masa inkubasi). Dalam masa istirahat guru belum diperkenankan untuk memberikan kritik dan komentar. Tahap selanjutnya adalah evaluasi gagasan. Peserta didik berdiskusi untuk meninjau dan memilah gagasan menjadi beberapa gagasan yang potensial untuk dikembangkan menjadi karangan argumentasi (Sani, 2013)

Keterampilan menulis karangan argumentasi mengalami kenaikan pada setiap pertemuan di masing-masing siklus setelah diterapkannya metode pembelajaran Brainstorming. Indikator kinerja penelitian yaitu sebesar $80 \%$ terlampaui pada akhir siklus II. Peningkatan keterampilan menulis karangan argumentasi pada peserta didik kelas V SD Negeri Sukabumi tahun ajaran 2020/2021 dapat diamati pada table 1 berikut: 
Volume 9 Nomor 1 Tahun 2021

Tabel 1. Perbandingan Hasil Tindakan antar Pertemuan

\begin{tabular}{lcccc}
\hline \multicolumn{1}{c}{ Keterangan } & $\begin{array}{c}\text { Siklus I } \\
\text { Pertemuan 1 }\end{array}$ & $\begin{array}{c}\text { Siklus I } \\
\text { Pertemuan 2 }\end{array}$ & $\begin{array}{c}\text { Siklus II } \\
\text { Pertemuan 1 }\end{array}$ & $\begin{array}{c}\text { Siklus II } \\
\text { Pertemuan 2 }\end{array}$ \\
\hline Nilai terendah & 30 & 35 & 50 & 55 \\
Nilai tertinggi & 85 & 92,5 & 92,5 & 92,5 \\
Nilai rata-rata klasikal & 61,57 & 70,46 & 77,31 & 79,26 \\
Ketuntasan klasikal & $33 \%$ & $59 \%$ & $74 \%$ & $81 \%$ \\
\hline
\end{tabular}

Berdasarkan tabel 1, peningkatan hasil tindakan antar pertemuan ditunjukkan dari peningkatan nilai terendah, tertinggi, rata-rata, dan ketuntasan klasikal. Nilai terendah pada siklus I pertemuan I adalah 30 , naik menjadi 35 pada siklus I pertemuan 2, dan terus meningkat menjadi 50 dan 55 pada siklus II pertemuan 1 dan 2 secara berturut-turut. Nilai tertinggi pada siklus I pertemuan 1 adalah 85 dan naik menjadi 92,5 pada pertemuan-pertemuan selanjutnya. Rata-rata klasikal secara berturut turut juga mengalami peningkatan dari 61.57 menjadi $70.46,77.31$, dan 79.26 pada pertemuan terakhir. Persentase ketuntasan klasikal secara berturut-turut adalah 33\%, 59\%, 74\% dan $81 \%$ pada akhir siklus II. Ketuntasan klasikal pada akhir siklus II yaitu $81 \%$ sudah berhasil melampaui indikator kinerja penelitian yang ditentukan yaitu $80 \%$. Penerapan metode pembelajaran Brainstorming untuk meningkatkan keterampilan menulis karanga argumentasi pada peserta didik kelas V SD Negeri Sukabumi tahun ajaran 2020/2021 dinyatakan berhasil dan dihentikan pada siklus kedua.

Temuan pada PTK ini adalah meningkatnya partisipasi aktif peserta didik dalam pembelajaran menulis karangan argumentasi. Peningkatan ini karena langkah-langkah operasional dalam metode pembelajaran Brainstorming secara spesifik membiasakan peserta didik terlibat untuk mengungkapkan gagasan dalam bentuk tulisan. Hal tersebut mengakibatkan meningkatnya keterampilan menulis karangan argumentasi peserta didik kelas V SD Negeri Sukabumi tahun ajaran 2020/2021 Hal ini sesuai dengan pendapat dari Khalid Khalaf (2018) yang menjelaskan bahwa adanya keterlibatan peserta didik dalam pembelajaran menjadikan pembelajaran lebih berkesan (pembelajaran bermakna), sehingga dapat mengembangkan/ meningkatkan keterampilan, pengalaman, dan kemampuan peserta didik.

Penerapan metode Brainstorming dalam pembelajaran menulis karangan argumentasi pada peserta didik kelas V SD Negeri Sukabumi memfasilitasi peserta didik untuk terlibat aktif menghimpun gagasan-gagasan yang berbeda dan memilahnya untuk disusun secara sistematis dalam bentuk karangan argumentasi. Hal tersebut sejalan dengan pendapat Roestiyah (2013) mengenai kelebihan metode pembelajaran Brainstorming. Kelebihan metode pembelajaran Brainstorming antara lain: 1)Peserta didik berfikir aktif untuk menyatakan argument; 2) Membiasakan pola pikir cekatan dan masuk akal ; 3) Memacu peserta didik untuk siap sedia untuk berargumen; 4)Meningkatkan keterlibatan peserta didik secara aktif dalam pembelajaran ; dan 5) Suasana pembelajaran berlangsung demokratis.

Ketuntasan klasikal yang meningkat setiap pertemuan dalam 2 siklus membuktikan bahwa metode pembelajaran Brainstorming dapat meningkatkan keterampilan menulis karangan argumentasi pada peserta didik kelas V SD Negeri Sukabumi tahun ajaran 2020/2021. Persentase ketuntasan klasikal secara berturutturut adalah $33 \%, 59 \%$, 74\% dan mencapai $81 \%$ pada akhir siklus II.

Hal tersebut selaras dengan penelitian Amin (2016) dalam Jurnal Pendidikan Sejarah dengan judul "Penerapan Metode Curah Gagasan (Brainstorming) untuk Meningkatkan Kemampuan Mengemukakan Pendapat Siswa" yang menyimpulkan bahwa penerapan metode Brainstorming dapat meningkatkan kemampuan peserta didik dalam mengemukakan pendapat. Dibuktikan dari hasil tindakan yang mengalami peningkatan. Kemampuan peserta didik dalam mengemukakan pendapat pada 
tindakan pertama menunjukkan presentasi 35\% dan masih dalam kategori cukup. Peningkatan mulai terlihat pada tindakan II dengan persentase $41 \%$, tindakan III dengan persentase $73 \%$, dan tindakan IV dengan presentasi $82 \%$ dengan kategori baik. Pemaparan di atas membuktikan bahwa hasil dari PTK ini relevan dengan penelitian-penelitian sebelumnya. Penelitian relevan tersebut dapat memperkuat hasil PTK ini.

\section{SIMPULAN}

Berdasarkan hasil penelitian ini, dapat disimpulkan bahwa penerapan metode pembelajaran Brainstorming dapat meningkatkan keterampilan menulis karangan argumentasi pada peserta didik kelas V SD Negeri Sukabumi tahun ajaran 2020/2021. Penelitian ini secara teoretis memiliki implikasi sebagai referensi dan pertimbangan untuk penelitian sejenis dan secara praktis dapat meningkatkan keterampilan menulis karangan argumentasi serta bahan pertimbangan dalam memilih metode pembelajaran yang tepat. Penulis memberi rekomendasi kepada guru untuk lebih selektif dalam memilih metode pembelajaran sesuai dengan materi dan bagi sekolah agar secara konsisten memberikan fasilitas bagi pengembangan profesionalisme guru.

\section{DAFTAR PUSTAKA}

Amin, D. N. F. (2016). Penerapan Metode Curah Gagasan (Brainstorming) untuk Meningkatkan Kemampuan Mengemukakan Pendapat Siswa. Jurnal Pendidikan Sejarah, 5 N0.2.

Atmazaki. (2013). Mengungkap Masa Depan: Inovasi Pembelajaran Bahasa Indonesia dalam Konteks Pengembangan Karakter Cerdas.

Dalman. (2016). Keterampilan Menulis (6th ed.). Jakarta : Raja Grafindo Persada.

Harianti, A., \& Margaretha, Y. (n.d.). Pengembangan Kreativitas Mahasiswa dengan Menggunakan Metode Brainstorming dalam Mata Kuliah Kewirausahaan. Jurnal Manajeman Universitas Kristen Maranatha, 13 No.2.

Keraf, G. (2011). Argumentasi dan Narasi (13th ed.). Jakarta : Gramedia Pustaka Utama.

Khalid Khalaf, B. (2018). Traditional and Inquiry-Based Learning Pedagogy: A Systematic Critical Review. International Journal of Instruction.

Kosasih, E. (2003). Kompetensi Ketatabahasaan dan Kesusastraan. Bandung : Yrama Widya.

Mulyati, Y. (2015). Keterampilan Berbahasa Indonesia SD. Jakarta : Universitas Terbuka.

Ngalimun, \& Alfulaila, N. (2014). Pembelajaran Keterampilan Berbahasa Indonesia (II). Sleman : Aswaja Pressindo.

Reznitskaya, A., Anderson, R. C., \& Kuo, L.-J. (2016). Teaching and Learning Argumentation. The Elementary School Journal, 107 No.5, 450.

Roestiyah. (2013). Strategi Belajar Mengajar (7th ed.). Jakarta : PT Rineka Cipta.

Sani, R. A. (2013). Inovasi Pembelajaran (1st ed.). Jakarta : PT Bumi Aksara.

Slamet, S. Y. (2013). Dasar-dasar Keterampilan Berbahasa Indonesia: Surakarta : UNS Press. 